\title{
Media Katalog Digital Untuk Pembelajaran Sejarah Di Masa Pandemi Covid-19
}

\author{
Fahmi Nur Ramadhan, Sunardi, Akhmad Arif Musadad \\ Fahminr11@gmail.com, Sunardi.ipnus@gmail.com, \\ akhmadarifmussadad@staff.uns.ac.id \\ Universitas Sebelas Maret, Surakarta
}

\begin{abstract}
Various new problems emerged after history learning which is currently carried out online due to the Covid-19 virus pandemic. These new problems make the problems in history learning more diverse after conventional history learning also experiences many problems. Various problems that arise in online history learning such as students who are easily bored and tired, students who increasingly do not understand the material presented, students who are increasingly not interested in online history learning, students who do not always pay attention and are not easy to monitor after learning online history. The purpose of this research is to overcome various problems that occur due to online history learning through the use of the Digital History Catalog learning media. This study uses a research method in the form of descriptive qualitative research. The result showed that the use of appropriate, innovative, interactive learning media and being able to adapt to online learning was needed both by students and by the teachers themselves. Media such as the Digital History Catalog can overcome the problems that occur due to online history learning. Digital History Catalog Media can adjust the material to be delivered according to those listed in the KI (The main competencies) and KD (The basic competencies) of history learning.
\end{abstract}

Keywords: History Learning, Covid-19 Pandemic, History Digital Catalog.

\begin{abstract}
Abstrak
Berbagai permasalahan baru muncul setelah pembelajaran sejarah yang saat ini dilakukan secara online akibat terjadinya pandemi virus Covid-19. Masalah-masalah baru tersebut membuat masalah dalam pembelajaran sejarah semakin beragam setelah pembelajaran sejarah secara konvensional pun mengalami banyak permasalahan. Berbagai masalah yang muncul dalam pembelajaran sejarah online seperti misalnya siswa yang mudah cepat bosan dan lelah, siswa yang semakin tidak paham tentang materi yang disampaikan, siswa yang tidak tertarik dengan pembelajaran sejarah online, siswa tidak selalu memperhatikan dan tidak mudah untuk dipantau setelah dilakukannya pembelajaran sejarah online. Tujuan dari penelitian yang dilakukan ini ialah untuk mengatasi berbagai permasalah yang terjadi akibat pembelajaran sejarah online melalui sebuah penggunaan media pembelajaran Katalog Digital Sejarah. Penelitian ini menggunakan metode penelitian berupa penelitian kualitatif deskriptif. Hasil penelitian menunjukkan bahwa penggunaan media pembelajaran yang tepat, inovatif, dan interaktif serta mampu menyesuaikan dengan pembelajaran online sangat dibutuhkan baik oleh siswa maupun oleh guru sendiri. Media seperti Katalog Digital Sejarah dapat mengatasi permasalahanpermasalahan yang terjadi akibat pembelajaran sejarah online. Media Katalog Digital
\end{abstract}


Fahmi Nur Ramadhan, Sunardi, Akhmad Arif Musadad

Media Katalog Digital Untuk Pembelajaran Sejarah

Di Masa Pandemi Covid-19

Sejarah dapat menyesuaikan materi yang akan disampaikan sesuai dengan yang tercantum dalam KI dan KD pembelajaran sejarah.

Kata Kunci: Pembelajaran Sejarah; Pandemi Covid-19; Katalog Digital Sejarah

\begin{tabular}{|c|c|}
\hline (c) (7) (2) & $\begin{array}{l}\text { This work is licensed under the Creative Commons Attribution-Share } \\
\text { International License }\end{array}$ \\
\hline
\end{tabular}

\section{Pendahuluan}

Sejarah sebagai salah satu cabang ilmu pengetahuan humaniora merupakan mata pelajaran yang dianggap cukup fundamental untuk diajarkan sebagai upaya memberikan wawasan tentang identitas sebagai seorang individu dan menumbuhkan kesadaran kolektif. Perjalanan manusia di dalam sejarah melalui berbagai tantangan dalam dimensi ruang dan waktu secara objektif (Black, J., \& MacRaild, 2000; Korostelina, 2008). Dengan kata lain, perjalanan manusia di dalam sejarah adalah sebuah proses pembentukan peradaban dengan berbagai perubahan, gejala dan pola yang terjadi dari masa lalu sampai masa kini (Weingold, 1972). Masa lalu yang ditulis menggunakan perangkat keilmuan oleh sejarawan bertujuan untuk memberikan pengetahuan kepada manusia yang hidup di masa kini tentang proses yang telah dijalani oleh manusia di masa sebelumnya. Produk hasil penelusuran aktivitas manusia di masa lalu yang ditulis kembali dikenal dengan historiografi (Gottschalk, 1969; Kuntowijoyo, 1995). Produk inilah yang nantinya akan dijadikan bahan utama dalam mempelajari sejarah, khususnya dalam ruang lingkup yang lebih formal yakni sekolah, dalam konteks pembelajaran sejarah (Mahardika, 2020).

Pembelajaran sejarah memiliki sebuah tujuan yang teramat penting, bukan hanya sebuah proses transfer of knowledge, bahkan lebih dari itu, pembelajaran sejarah merupakan sebuah proses untuk mewariskan nilai-nilai luhur yang terkandung pada suatu peristiwa masa lalu yang dapat digali dan dapat dimanfaatkan dengan sangat baik untuk menghadapi masalah untuk saat ini dan masa yang akan datang. Suatu inti dari pendidikan tidak akan berjalan seperti seharusnya tanpa dukungan dari sejarah. Sebab, sejarah memberikan bahan-bahan bagi terlaksananya suatu proses pengembangan manusia. Hal tersebut menunjukkan bahwa terdapat hubungan erat yang tidak dapat dipisahkan antara sejarah dan pendidikan (Carr, 2018; Freedman, 2005; Whittle, A., \& Wilson, 2015; Widja, 1989). Pernyataan mengenai pewarisan nilai tersebut sangat selaras dengan apa yang tercantum dalam tujuan pembelajaran sejarah dalam kurikulum 2013. Tujuan tersebut ialah menciptakan siswa yang sadar akan dirinya merupakan bagian dari bangsa Indonesia sehingga memiliki rasa 
bangga dan cinta tanah air yang kemudian melahirkan perilaku berdasarkan nilai dan moral yang sesuai dengan karakter diri, masyarakat, dan bangsa yang berorientasi pada masa kini dan masa depan (Kemendikbud, 2013; Nordgren, 2017).

Tujuan yang sangat penting tersebut nyatanya tidak selaras dengan apa yang terjadi di lapangan. Pembelajaran sejarah hingga saat ini justru dipandang sebelah mata oleh guru mata pelajaran lain, siswa, atau masyarakat secara umum (Mahardika, 2021). Apalagi siswa yang merasakan langsung selalu menganggap mata pelajaran sejarah hanya sebuah selingan semata. Siswa selalu berpendapat pembelajaran sejarah sangat membosankan karena tidak memberikan makna terhadap kehidupan siswa (Mahardika, 2021). Keadaan ini diperparah ketika pembelajaran sejarah dilakukan secara online akibat adanya pandemi Covid-19 yang terjadi. Problematika yang dihadapi oleh guru sejarah dalam pembelajaran online mengindikasi bahwa beralihnya sistem pembelajaran offline menuju online tidak serta merta menghasilkan perubahan positif dalam pendidikan. Justru yang ada ialah melahirkan sebuah tantangan baru bagi guru dan elemen-elemen terkait untuk menyelesaikan permasalahan yang terjadi, seperti pengorganisasian kelas yang belum teratur, waktu belajar yang tidak rasional, metode yang digunakan terlalu monoton, sulitnya menerapkan pendekatan dalam pembelajaran, dan inovasi penggunaan media yang masih sangat minim dimanfaatkan (Kurniawan, 2020).

Secara keseluruhan di sekolah, permasalahan tersebut tidak juga sepenuhnya diakibatkan oleh sistem pembelajaran secara online, melainkan bisa jadi disebabkan oleh perangkat pembelajaran yang tidak sepenuhnya mendukung. Faktor lain adalah akibat dari metode pengajaran yang digunakan terlalu monoton dan terkesan kurang memiliki inovasi (Mahardika, 2021). Lemahnya penggunaan teori, kurangnya imajinasi, terlalu mengacu pada buku teks, kurikulum yang cenderung state oriented, apalagi dengan pembelajaran yang tidak memperhatikan fenomena globalisasi yang terjadi (Subakti, 2010). Guru hanya menyampaikan fakta-fakta, urutan tahun, dan peristiwa saja. Kecenderungan-kecenderungan inilah yang kemudian memberikan kesan tidak menarik, membosankan, dan tidak menyenangkan kepada siswa terhadap mata pelajaran sejarah (Agung, L., \& Wahyuni, 2013).

Permasalahan seperti yang telah dijelaskan juga terjadi di sekolah SMA Negeri 2 Majalengka. Setelah dilakukannya penyebaran angket dan wawancara dengan guru sejarah yang bersangkutan, terdapat banyak sekali permasalahan yang timbul dengan dilakukannya pembelajaran secara online. Terutama dalam hal penggunaan teknologi yang masih kurang dimanfaatkan dalam 
Fahmi Nur Ramadhan, Sunardi, Akhmad Arif Musadad

Media Katalog Digital Untuk Pembelajaran Sejarah

Di Masa Pandemi Covid-19

pembelajaran sejarah online. Perlu adanya sebuah inovasi yang dilakukan dalam pemanfaatan teknologi terutama sebuah media pembelajaran.

Jika berbicara mengenai perangkat pembelajaran yang mendukung proses kegiatan belajar mengajar secara online, penggunaan sebuah media pembelajaran juga dapat dilakukan oleh guru. Seperti halnya media pembelajaran Katalog Digital Sejarah yang dapat menjadi alternatif solusi yang bagus untuk proses pembelajaran sejarah secara online. Penggunaan sebuah media pembelajaran ini dapat ditinjau dari manfaat penggunaan media pembelajaran, misalnya saja memberikan efek berupa rangsangan terhadap pikiran, perasaan, minat, dan perhatian siswa sehingga proses pembelajaran dapat berjalan secara efektif (Priansa, 2019; Westerby, G., \& Keegan, 2019).

Beberapa manfaat dari sebuah media pembelajaran dapat dirasakan selama proses pembelajaran berlangsung. Misalnya: a) Media pembelajaran mampu memberikan kejelasan sebuah pesan dan informasi, sehingga hasil pembelajaran dapat lancar dan meningkat; b) Media pembelajaran dapat memberikan peningkatan dalam motivasi belajar siswa secara mandiri; c) Keterbatasan ruang dan waktu dapat diatasi dengan memanfaatkan sebuah media pembelajaran; d) Berbagai objek yang besar atau kecil dapat ditampilkan ke dalam sebuah media pembelajaran; e) Suatu kejadian masa lalu yang hanya terjadi satu kali atau sebuah fenomena yang berlangsung lama dapat ditampilkan oleh sebuah media pembelajaran (Arsyad, 2013; Sulistyo et al., 2021).

Penggunaan media sangat penting dalam sebuah proses pembelajaran, hal ini dimaksudkan untuk memancing daya tarik siswa akan materi yang disampaikan oleh guru secara lebih aktif. Maka, media yang digunakan haruslah menarik untuk memunculkan kesan positif dalam diri siswa, sehingga pembelajaran akan jauh lebih bermakna dan tidak monoton (Mahardika, M. D \& Putra, 2020; Widalismana, M., Baedhowi, \& Sawiji, 2016).

Poin utama dalam pembahasan artikel ini adalah media pembelajaran Katalog Digital Sejarah yang disajikan dengan bentuk yang lebih modern menyesuaikan dengan pembelajaran sejarah online. Media Katalog Digital Sejarah dapat diisi dengan berbagai materi, gambar, video, audio, hingga bentuk assessment yang disesuaikan dengan keinginan guru sejarah. Akses penggunaan media Katalog Digital Sejarah sangat mudah dilakukan baik oleh guru maupun siswa dengan menggunakan perangkat elektronik yang dimiliki oleh masing-masing. Katalog Digital Sejarah menciptakan sebuah media pembelajaran yang inovatif dan interaktif dalam pembelajaran sejarah secara online akibat pandemi Covid-19 (Lei \& So, 2021; Wynne, 2009). 
Media Katalog Digital Sejarah ini dapat dikatakan sebagai sebuah bagian dari Learning Management System (LSM). Learning Management System (LSM) sendiri merupakan sebuah perangkat lunak atau software yang dapat digunakan untuk keperluan administrasi, dokumentasi, laporan dari sebuah kegiatan, kegiatan belajar mengajar, e-learning, dan materi-materi pelatihan yang ke semua itu dilakukan secara online (Ellis, 2009).

Dengan demikian, pengembangan Media Katalog Digital Sejarah dengan Learning Management System sebagai sebuah media pembelajaran menggunakan open source yang telah tersedia diharapkan mampu menarik perhatian siswa, menambah motivasi dan minat siswa, sehingga materi atau informasi yang akan diberikan kepada siswa mampu diserap oleh siswa dalam proses belajar mengajar.

Secara fisik, katalog terdiri dari sebuah rincian sebuah jenis produk dengan gambar-gambar (sejenis dengan brosur). Ukurannya menyesuaikan dengan kebutuhan dari penggunaan katalog dan dicetak dengan beberapa halaman yang dijilid hingga menyerupai sebuah buku. Katalog dibuat dengan tujuan untuk menyebarkan dan memberikan sebuah informasi (Kusrianto, 2007). Lebih jauh, fungsi dari sebuah katalog sendiri adalah sebagai sebuah sarana yang digunakan seseorang untuk menemukan dan memilih suatu informasi dari sebuah benda atau dokumen dengan edisi dan jenis tertentu (Dunkin, 1969). Lebih lengkap mengenai fungsi dari katalog adalah sebagai berikut: 1) Sebagai suatu catatan lengkap dari koleksi sebuah perpustakaan; 2) Sebagai kunci menemukan suatu karya yang diperlukan; 3) Sebagai sumber karya alternatif pilihan; 4) Sebagai sumber untuk menyusun sebuah bibliografi; 5) Sebagai sarana bantu untuk mengingat sebuah koleksi (Darmono, 2007).

Katalog sendiri memiliki banyak bentuk fisiknya, secara umum katalog terdiri dari empat bentuk yang biasa digunakan (Suhendar, 2007), yaitu: 1) Katalog berupa buku, merupakan katalog yang dicetak menjadi semacam bibliografi dan disusun secara sistematis sebanyak yang diperlukan. Kelebihannya adalah dapat dibawa kemana saja, namun kelemahannya terkait informasi baru yang tidak dapat ditambahkan secara langsung, melainkan harus diedit dan dicetak lagi; 2) Katalog berupa kartu, biasanya banyak digunakan di perpustakaan. Kelebihannya mampu menerima berbagai informasi baru tanpa harus mengubahnya; 3) Katalog berupa berkas, terdiri dari beberapa lembaran-lembaran lepas yang dimuat menjadi satu dan berisikan informasi di dalamnya. Bentuk ini hampir sama dengan katalog buku, namun lebih simple; 4) Katalog berupa elektronik, dapat diakses melalui sebuah perangkat elektronik seperti handphone, laptop, atau PC. Banyak kelebihan dari 
Fahmi Nur Ramadhan, Sunardi, Akhmad Arif Musadad

Media Katalog Digital Untuk Pembelajaran Sejarah

Di Masa Pandemi Covid-19

katalog jenis satu ini, namun kelemahannya ialah file yang termuat dalam katalog rentan hilang dan terkena virus serta masalah teknis lainnya.

Penggunaan dan pemanfaatan media pembelajaran Katalog Digital ini sudah dilakukan dalam berbagai penelitian yang berbeda. Pertama, penelitian yang dilakukan di tahun 2018 oleh Agustina dan Amboro. Penelitian ini diterbitkan di jurnal Swarnadwipa vol. 2 no. 3 dengan judul "Pengembangan Desain Media Pembelajaran Berbasis Katalog Digital Peninggalan Sejarah Lokal untuk Menguatkan Pemahaman Sejarah Lokal Siswa di SMA Negeri 3 Menggala Tulang Bawang". Tujuan penelitiannya sendiri ialah untuk melihat kelayakan dari penggunaan media katalog. Media katalog yang digunakan dalam penelitian ini berisikan materi mengenai sejarah perang melawan kolonialisme, kedatangan dan kekuasaan VOC, dampak pemerintah Belanda di kelas XI. Digunakan juga di kelas $\mathrm{X}$ dengan materi penyebaran agama Islam di Nusantara dan pemahaman siswa akan sejarah lokal. Penelitian ini menggunakan metode penelitian dan pengembangan Sugiyono level 1, artinya hanya sampai tahap menguji kelayakan penggunaan media Katalog dalam pembelajaran sejarah. Hasilnya menunjukkan bahwa media pembelajaran Katalog sangat layak untuk digunakan dan diujicobakan dalam pembelajaran sejarah di sekolah (Agustina \& Amboro, 2018).

Penelitian terbaru dilakukan juga di tahun 2021 ini dengan judul "Desain Media Katalog Digital Museum Airlangga untuk Siswa kelas X SMA Negeri 1 Plosoklaten Kediri". Penelitian ini dilakukan oleh Muhtiya Wahyu Afi, Joko Sayono, dan Wahyu Djoko Sulistyo. Penelitian yang diterbitkan pada journal of Education, Humaniora, and Social Sciences (JEHSS) vol. 4, no. 1 terdiri dari 229238 halaman. Tujuan penelitian ini adalah untuk mengembangkan sebuah desain media pembelajaran katalog digital Museum Airlangga yang dikemas dalam bentuk aplikasi smartphone secara offline. Media katalog tersebut berisikan benda-benda peninggalan pada masa kerajaan Hindu-Buddha yang terdapat di Museum Airlangga. Penelitiannya sendiri menggunakan metode ADDIE (Analisis, perancangan, pengembangan, evaluasi, dan implementasi). Hasil penelitian menunjukkan bahwa penggunaan media Katalog Digital lebih efektif dan efisien digunakan dalam pembelajaran sejarah selama pandemi tanpa harus berkunjung ke museum Airlangga (Afi et al., 2021).

Setelah menjelaskan latar belakang masalah dan penelitian terdahulu yang telah dilaksanakan, maka penelitian dan penulisan artikel ini bertujuan untuk melihat bagaimana pemanfaatan media pembelajaran Katalog Digital Sejarah dalam pembelajaran sejarah yang dilakukan secara online. Penggunaan media pembelajaran Katalog Digital diharapkan mampu mengatasi berbagai macam 
permasalahan yang terjadi dan dihadapi baik oleh guru dan siswa dalam pembelajaran online. Perlu atau tidaknya penggunaan sebuah media pembelajaran yang inovatif dan interaktif dalam pembelajaran sejarah online seperti media pembelajaran Katalog Digital Sejarah di tengah pandemi Covid19.

\section{Metode Penelitian}

Metode penelitian yang digunakan adalah metode penelitian Kualitatif Deskriptif dengan teknik triangulasi data. Data penelitian didapatkan dari sekolah SMA Negeri 2 Majalengka melalui 3 tahapan (Sugiyono, 2014), yaitu: 1) Wawancara dengan 1 orang guru sejarah dan 3 orang siswa yang mewakili keseluruhan siswa kelas XI IPS; 2) Penyebaran angket melalui link google form kepada 6 kelas XI IPS. Angket terdiri dari 9 pernyataan yang harus dijawab oleh siswa sesuai dengan keadaan yang dirasakan oleh siswa. Kriterianya sendiri terdiri dari SS=Sangat setuju, S=Setuju, TS=Tidak setuju, dan STS=Sangat tidak setuju. Hasil proses penyebaran angket sendiri diperoleh sebanyak 93 responden dengan data yang dianalisis secara deskriptif kemudian; dan terakhir 3) Analisis dokumen berupa Silabus dan RPP yang digunakan oleh guru dalam pembelajaran sejarah online.

\section{Hasil dan Pembahasan Penelitian}

\section{Hasil Analisis Kebutuhan untuk Pembelajaran Sejarah di Masa Pandemi Covid-19}

Berdasarkan hasil dari penyebaran angket yang telah dilakukan dan telah diisi oleh siswa kelas XI IPS di sekolah SMA Negeri 2 Majalengka, diperoleh 93 responden dari 6 kelas XI IPS dan menunjukkan hasil data pada gambar sebagai berikut: Keterangan: $S S=$ Sangat Setuju, S=Setuju, TS=Tidak Setuju, STS= Sangat Tidak Setuju 
Fahmi Nur Ramadhan, Sunardi, Akhmad Arif Musadad

Media Katalog Digital Untuk Pembelajaran Sejarah

Di Masa Pandemi Covid-19

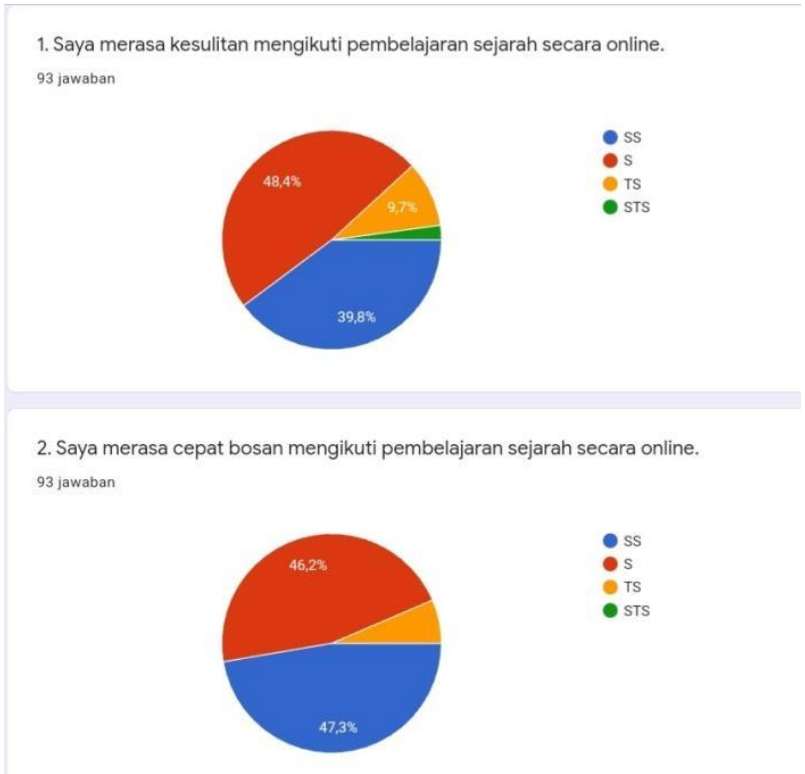

Gambar 1. Rekapitulasi Angket Analisis Kebutuhan Pernyataan 1 dan 2 Sumber: Dokumen pribadi peneliti, 2021

Gambar 1 menunjukkan pernyataan 1 mengenai "Saya merasa kesulitan mengikuti pembelajaran sejarah secara online" dan pernyataan 2 mengenai "Saya merasa cepat bosan mengikuti pembelajaran sejarah secara online". Hasilnya menunjukkan pernyataan 1 menjawab SS sebesar 39,8\%, S sebesar $48,4 \%$, TS sebesar 9,7\%. Hasil pernyataan 2 menunjukkan jawaban SS sebesar $47,3 \%$, dan $S$ sebesar $46,2 \%$.

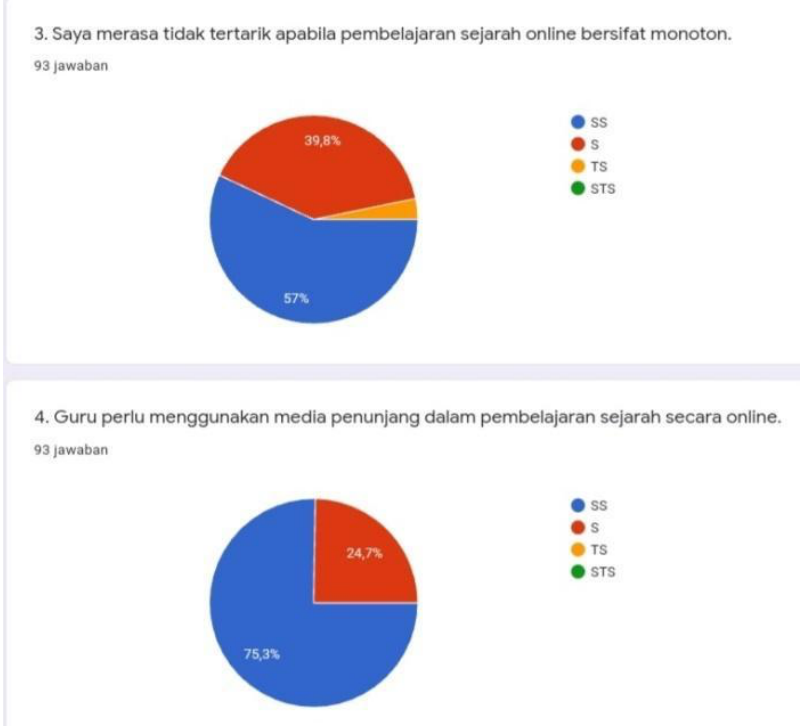

Gambar 2. Rekapitulasi Angket Analisis Kebutuhan Pernyataan 3 dan 4 Sumber: Dokumen pribadi peneliti, 2021

Gambar 2 menunjukkan pernyataan 3 mengenai "Saya merasa tidak tertarik apabila pembelajaran sejarah online bersifat monoton" dan pernyataan 4 
mengenai "Guru perlu menggunakan media penunjang dalam pembelajaran sejarah secara online". Hasilnya menunjukkan pernyataan 3 menjawab SS sebesar $57 \%$, S sebesar 39,8\%. Hasil pernyataan 4 menunjukkan jawaban SS sebesar $75,3 \%$, dan S sebesar $24,7 \%$.

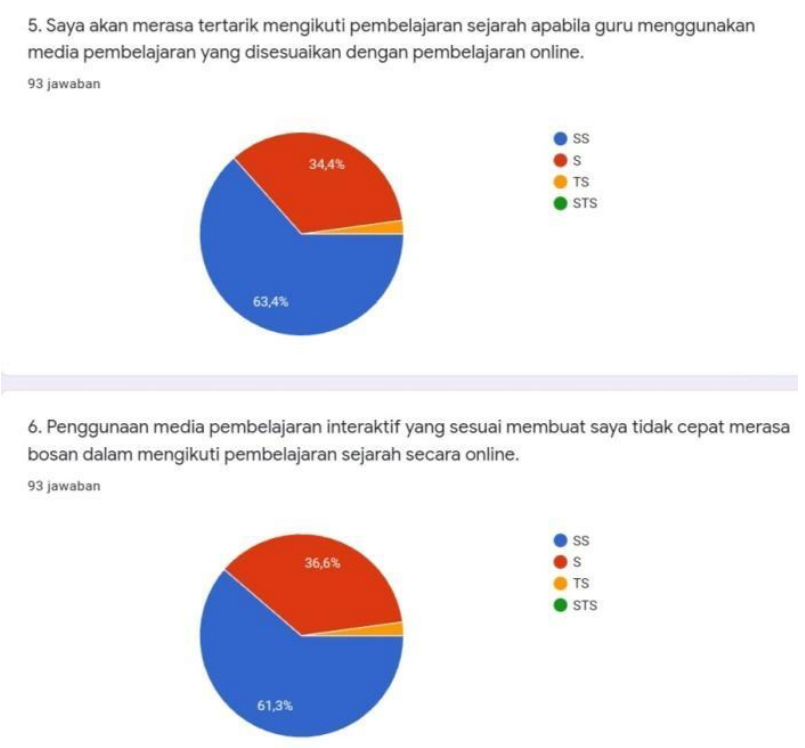

Gambar 3. Rekapitulasi Angket Analisis Kebutuhan Pernyataan 5 dan 6 Sumber: Dokumen pribadi peneliti, 2021

Gambar 3 menunjukkan pernyataan 5 mengenai "Saya akan merasa tertarik mengikuti pembelajaran sejarah apabila guru menggunakan media pembelajaran yang disesuaikan dengan pembelajaran online" dan pernyataan 6 mengenai "Penggunaan media pembelajaran interaktif yang sesuai membuat saya tidak cepat merasa bosan dalam mengikuti pembelajaran sejarah secara online". Hasilnya menunjukkan pernyataan 1 menjawab SS sebesar 63,4\%, S sebesar 34,4\%. Hasil pernyataan 2 menunjukkan jawaban SS sebesar $61,3 \%$, dan S sebesar $36,6 \%$. 


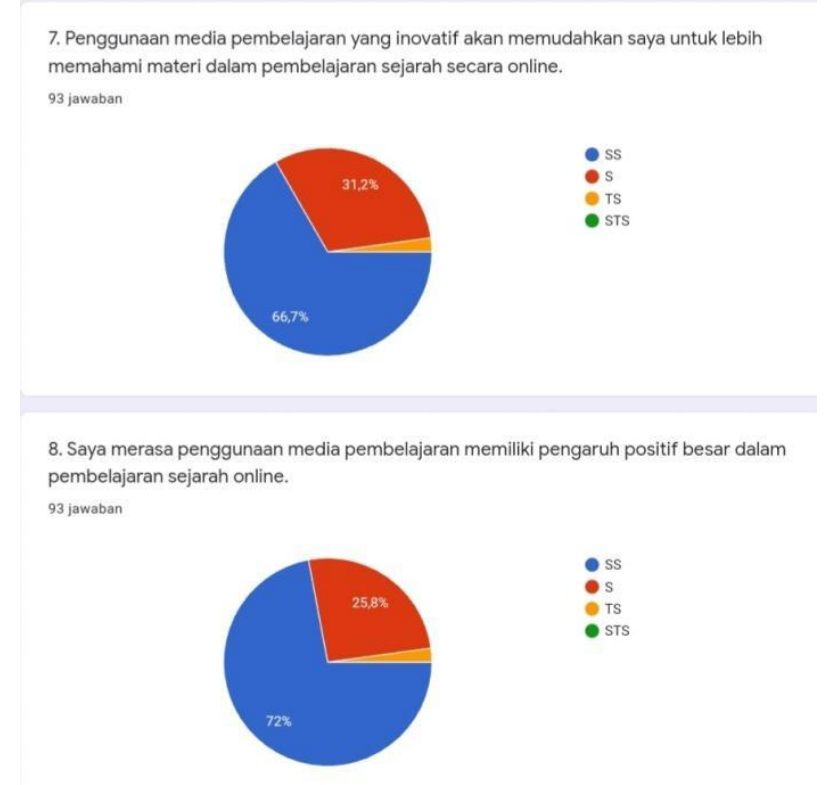

Gambar 4. Rekapitulasi Angket Analisis Kebutuhan Pernyataan 7 dan 8 Sumber: Dokumen Pribadi Peneliti, 2021

Gambar 4 menunjukkan pernyataan 7 mengenai "Penggunaan media pembelajaran yang inovatif akan memudahkan saya untuk lebih memahami materi dalam pembelajaran sejarah online" dan pernyataan 6 mengenai "Saya merasa penggunaan media pembelajaran memiliki pengaruh positif besar dalam pembelajaran sejarah online". Hasilnya menunjukkan pernyataan 1 menjawab SS sebesar 63,4\%, S sebesar 34,4\%. Hasil pernyataan 2 menunjukkan jawaban SS sebesar 61,3\%, dan S sebesar 36,6\%.

Hasil data yang telah diperoleh menunjukkan beberapa hasil penjelasan sebagai berikut:

1. Selama pembelajaran online, siswa mengalami kesulitan, mudah merasa bosan, dan tidak tertarik mengikuti pembelajaran sejarah.

2. Siswa mendukung secara penuh penggunaan sebuah media pembelajaran yang menunjang pembelajaran sejarah via online oleh guru yang bersangkutan.

3. Siswa menganggap akan lebih tertarik, lebih mudah memahami materi, dan tidak akan cepat merasa bosan bila guru menggunakan media pembelajaran yang interaktif dan inovatif dalam menunjang pembelajaran sejarah via online.

4. Siswa menganggap penggunaan media pembelajaran sejarah online memiliki dampak positif dalam perkembangan belajar mereka. 
5. Terakhir, siswa mendukung secara penuh adanya pengembangan media pembelajaran inovatif dan interaktif untuk menunjang pembelajaran sejarah online seperti Media Katalog Digital Sejarah.

Itulah beberapa penjelasan yang didapatkan atas hasil penyebaran angket analisis kebutuhan pada siswa kelas XI IPS di SMA Negeri 2 Majalengka sekaligus untuk melihat pendapat mereka tentang pemanfaatan media pembelajaran sejarah yang menunjang pembelajaran sejarah online.

Hasil angket kemudian diperkuat dengan hasil wawancara yang dilakukan kepada seorang guru sejarah bernama Ibu Inggit Andini Mentari dan 3 orang siswa yang mewakili 6 kelas XI IPS pada tanggal 25 Maret 2021. Ibu Inggit menuturkan bahwa siswa sendiri lebih cepat bosan, kesulitan dalam mengikuti pembelajaran, dan juga berkurangnya keterkaitan siswa akan pembelajaran sejarah setelah dilakukan secara online. Kecenderungan ini terlihat dari adanya siswa yang hanya absen saja tanpa mengikuti kelas online, ada yang mematikan kamera dan audio, siswa yang cenderung diam saat diberikan pertanyaan oleh guru ataupun sebaliknya tidak ada siswa yang bertanya kepada guru akan materi yang diajarkan. Pendapat mengenai penggunaan media pembelajaran sendiri beliau mengakui bahwa sudah menggunakan media pembelajaran power point untuk mendukung pembelajaran sejarah online. namun, memang penggunaan media tersebut tidak dapat maksimal dan tidak bersifat interaktif. Dengan demikian, perlu adanya sebuah media pembelajaran yang menunjang pembelajaran sejarah secara online. Beliau mendukung penuh penggunaan media pembelajaran Katalog Digital Sejarah.

Selain itu, dilakukan pula wawancara bersama 3 orang siswa yang mewakili 6 kelas XI IPS di SMA Negeri 2 Majalengka. Ketiga siswa menuturkan bahwa memang banyak sekali kendala yang mereka alami dalam pembelajaran sejarah online yang menghambat proses pembelajaran. Ketiganya berpendapat dengan tatap muka saja, pelajaran sejarah terkadang sangat sulit untuk dipahami karena sifatnya yang imajinatif tanpa adanya gambaran yang nyata dan jelas (berupa cerita saja). Apalagi dengan pembelajaran online ini siswa lebih memiliki tingkat kesulitan yang lebih lagi dalam memahami materi yang disampaikan. Ditambah dengan rasa bosan, rasa lelah, dan mengantuk yang terasa semakin cepat datang menjadi kendala yang sulit dihindari oleh siswa sendiri. Maka, ketiga siswa tersebut sepakat dengan kompak bahwa untuk mengatasi masalah-masalah tersebut penggunaan media pembelajaran seperti Katalog Digital Sejarah sangat diperlukan dan sangat memungkinkan untuk membantu mereka dalam pembelajaran sejarah online. 
Melihat hasil penyebaran angket dan hasil wawancara yang dilakukan, penggunaan media Katalog Digital Sejarah dapat menjadi alternatif solusi yang dapat digunakan oleh guru. Sebagai contoh, media Katalog Digital Sejarah dapat disesuaikan dengan materi pelajaran sejarah peminatan dengan KD 3.7 mengenai Penelitian dan Penulisan Sejarah. Kompetensi Dasar (KD) tersebut dikolaborasikan dengan pengenalan potensi sejarah lokal kepada siswa melalui sebuah penelitian dan penulisan dari situs-situs sejarah lokal yang ada di Majalengka, misalnya dengan gambar, teks, video, audio yang disediakan. Siswa sendiri dapat mengaksesnya melalui ponsel, laptop, atau PC dengan sangat mudah.

Selain itu, media Katalog Digital Sejarah ini dapat memuat sebuah assessment yang langsung tertaut pada google form berupa soal-soal dengan materi terkait. Ketika diakhir pembelajaran atau setelah kegiatan belajar mengajar berakhir, siswa dapat memberikan informasi mengenai materi yang tertuang dalam media Katalog Digital Sejarah melalui media sosial mereka masing-masing seperti Facebook, Instagram, atau Twitter. Itulah sebuah contoh penggunaan media pembelajaran Katalog Digital Sejarah dalam mendukung pembelajaran sejarah online.

\section{Spesifikasi Produk/Prototype Produk Media Katalog Digital Sejarah untuk Pembelajaran Sejarah Online}

Setelah mengetahui bahwa kebutuhan media pembelajaran online seperti Katalog Digital Sejarah sangat dibutuhkan oleh guru dan siswa melalui hasil penyebaran angket dan hasil wawancara, maka tahap selanjutnya adalah merumuskan spesifikasi produk atau prototype dari produk yang diinginkan. Berikut ini merupakan draft dari media Katalog Digital Sejarah yang terdiri dari:

1. Halaman Cover

Bagian pertama ialah halaman cover yang memuat judul media dan identitas pengembang media. Agar lebih jelasnya dapat memperhatikan gambar di bawah ini. 


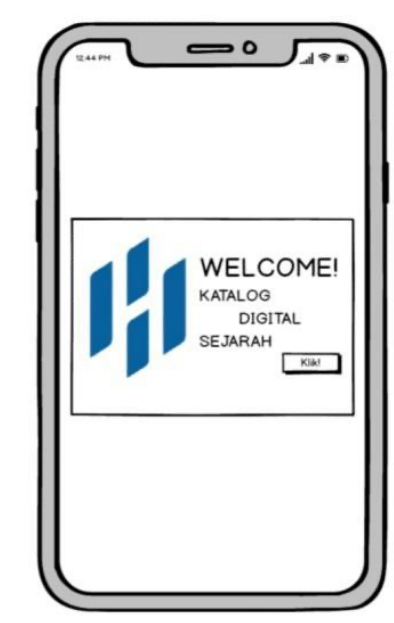

Gambar 5. Halaman Cover

Sumber: Dokumen Pribadi

\section{Halaman Home}

Bagian kedua ialah halaman home yang akan muncul setelah pengakses meng-klik tombol yang diperintahkan di halaman cover. Halaman home ini memuat deskripsi halaman home sendiri dan berbagai katalog sejarah berupa gambar-gambar yang terdiri dari beberapa situs sejarah lokal yang ada di Majalengka. Agar lebih jelasnya dapat dilihat gambar di bawah ini.

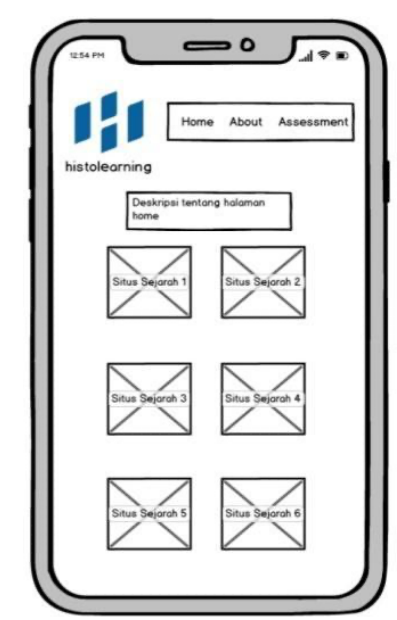

Gambar 6. Halaman Home

Sumber: Dokumen pribadi

\section{Halaman About}

Bagian ketiga ialah halaman about yang merupakan halaman yang memuat deskripsi mengenai Katalog Digital Sejarah dan deskripsi identitas penulis atau pengembang media secara lengkap. Agar lebih jelasnya dapat melihat gambar di bawah ini. 


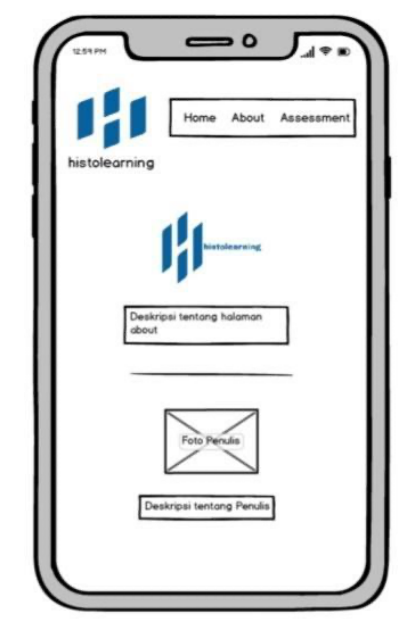

Gambar 7. Halaman About Sumber: Dokumen pribadi

\section{Halaman Assessment}

Halaman assessment adalah bagian keempat yang akan muncul dalam media. Membuat akses kepada siswa untuk mengerjakan soal evaluasi yang termuat dalam media Katalog Digital Sejarah. Halaman ini berisikan deskripsi dari halaman assessment, gambar, deskripsi jumlah dan jenis soal, dan link yang terkait pada google form. Agar lebih jelasnya dapat melihat gambar di bawah ini.

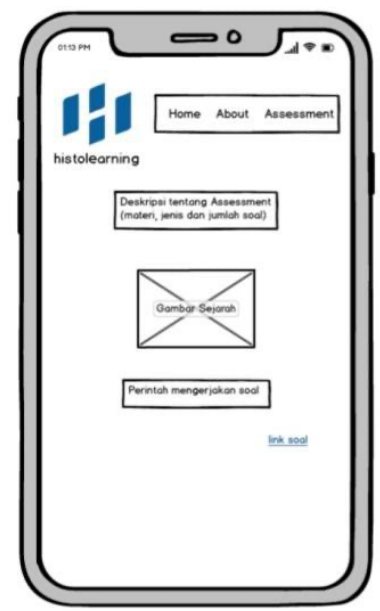

Gambar 8. Halaman Assessment

Sumber: Dokumen pribadi

\section{Halaman Isi}

Bagian terakhir dari media Katalog Digital Sejarah ialah halaman isi yang terletak di halaman home. Isinya sendiri terdiri dari gambar-gambar situs sejarah lokal yang ada di Majalengka. Ketika mengakses mengklik gambar yang diinginkan, mereka akan masuk ke halaman isi ini. Halaman isi tersebut terdiri dari sebuah video, gambar, deskripsi dari situs sejarah yang memuat 
topik penulisan: 1) Lokasi; 2) Sejarah; 3) Keadaan saat ini; dan 4) Upaya pelestarian.

Terakhir terdapat link share yang terkait pada akun media sosial siswa yang dapat digunakan seperti Facebook, Instagram, atau Twitter. Agar lebih jelasnya dapat melihat gambar di bawah ini.

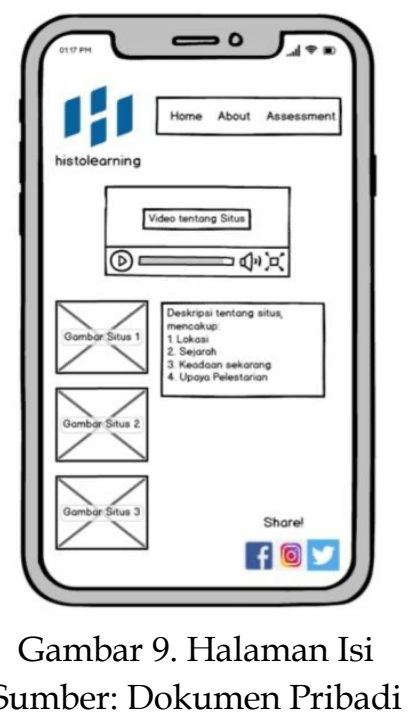

Itulah gambaran beberapa bagian (prototype) dari media Katalog Digital Sejarah yang dapat dikembangkan dan digunakan untuk mendukung pembelajaran sejarah secara online. Pengembangan dan penggunaan media Katalog Digital Sejarah ini diharapkan mampu mengatasi berbagai permasalahan yang muncul dalam pembelajaran sejarah secara online.

\section{Simpulan}

Berdasarkan hasil pengumpulan data melalui angket yang disebarkan kepada siswa, data tersebut dapat menjabarkan beberapa kesimpulan yang dapat menjadi acuan mengenai penerapan pembelajaran sejarah sistem online itu sendiri, bahwa diantaranya pertama, selama pembelajaran online, siswa mengalami kesulitan, mudah merasa bosan, dan tidak tertarik mengikuti pembelajaran sejarah. Kedua, siswa mendukung guru untuk menggunakan sebuah media pembelajaran yang menunjang pembelajaran sejarah online. Ketiga, Siswa merasa akan lebih tertarik, lebih mudah memahami materi, dan juga tidak akan cepat merasa bosan bila guru menggunakan media pembelajaran yang interaktif dan inovatif dalam menunjang pembelajaran sejarah online. Empat, Siswa menganggap penggunaan media pembelajaran sejarah online memiliki dampak yang positif dalam perkembangan belajar siswa. Lima, siswa mendukung secara penuh adanya pengembangan media 
Fahmi Nur Ramadhan, Sunardi, Akhmad Arif Musadad

Media Katalog Digital Untuk Pembelajaran Sejarah

Di Masa Pandemi Covid-19

pembelajaran inovatif dan interaktif untuk menunjang pembelajaran sejarah online seperti Media Katalog Digital Sejarah.

Salah satu penggunaan media pembelajaran yang dapat digunakan untuk menunjang proses pembelajaran sejarah online ialah media pembelajaran Katalog Digital Sejarah. Katalog ini dapat digunakan oleh guru untuk menyampaikan materi yang diinginkan dan dapat diakses oleh siswa melalui ponsel atau laptop yang dimiliki. Terlebih lagi, media Katalog Digital Sejarah dilengkapi dengan gambar, video, dan juga program assessment yang dapat dikerjakan oleh siswa. Dengan demikian, media Katalog Digital Sejarah dapat dengan praktis dan akan sangat mampu membantu guru dan siswa dalam pembelajaran sejarah online. Seperti penelitian yang telah dilakukan oleh Afi et al., 2021; Agustina \& Amboro, 2018, dimana Media Katalog Digital dapat mengatasi berbagai masalah yang terjadi dalam pembelajaran sejarah.

Sebagai sebuah saran yang dapat dijadikan acuan untuk para peneliti selanjutnya, ialah untuk mengembangkan media pembelajaran Katalog Digital Sejarah ini dengan sebuah inovasi baru yang lebih beragam. Dengan demikian, media pembelajaran online akan lebih bervariasi dan tidak menjadi sebuah media yang monoton. Selain itu, untuk menciptakan media Katalog Digital ini sebagai sebuah aplikasi fleksibel yang nantinya dapat digunakan oleh beberapa guru mata pelajaran yang tidak hanya sejarah saja. Pengembangan sebuah media pembelajaran seperti itu, bertujuan agar dapat bermanfaat untuk semua orang.

\section{Daftar Rujukan}

Afi, M. W., Sayono, J., \& Sulistyo, W. D. (2021). Desain Media Katalog Digital Museum Airlangga untuk Siswa Kelas X SMAN 1 Plosoklaten Kediri. Journal of Education, Humaniora and Social Sciences (JEHSS), 4(1), 229-238.

Agung, L., \& Wahyuni, S. (2013). Perencanaan Pembelajaran Sejarah. Ombak.

Agustina, D., \& Amboro, K. (2018). Pengembangan Desain Media Pembelajaran

Berbasis Katalog Peninggalan Sejarah Lokal untuk Menguatkan

Pemahaman Sejarah Lokal Siswa di SMA Negeri 3 Menggala Tulang Bawang. Jurnal Swarnadwipa, 2(3), 165-178.

Arsyad, A. (2013). Media Pembelajaran (Edisi Revisi). Raja Grafindo.

Black, J., \& MacRaild, D. M. (2000). Studying History. Macmillan.

Carr, E. H. (2018). What is History? Penguin UK.

Darmono. (2007). Perpustakaan Sekolah: Pendekatan Aspek Manajemen dan Tata Kerja. Grasindo.

Dunkin, P. (1969). Cataloging. Library Association.

Ellis, R. K. (2009). Field Guide To Learning Management System. .American Society for Training Development (ASTD).

Freedman, E. B. (2005). History Education for Democratic Citizenship. Theory $\mathcal{E}$ 
Research in Social Education, 33(3), 432-437.

Gottschalk, L. (1969). Understanding History: A Primer of Historical Methodq. Knopf.

Kemendikbud. (2013). Kurikulum 2013 SMA/MA/MAK Mata Pelajaran Sejarah Indonesia. Kemendikbud.

Korostelina, K. (2008). History Education and Social Identity. Identity, 8(1), 2545.

Kuntowijoyo, D. R. (1995). Pengantar ilmu sejarah. Bentang Pustaka.

Kurniawan, G. F. (2020). Problematika Pembelajaran Sejarah dengan Sistem Daring. Diakronika, 20(2).

Kusrianto, A. (2007). Pengantar Desain Komunikasi Visual. Andi Offset.

Lei, S. I., \& So, A. S. I. (2021). Online Teaching and Learning Experiences During the COVID-19 Pandemic - A Comparison of Teacher and Student Perceptions. Journal of Hospitality E Tourism Education, 33(3), 148-162. https:/ / doi.org/https://doi.org/10.1080/10963758.2021.1907196

Mahardika, M. D. G., \& Putra, N. W. (2020). The Utilization Interactive Digital Media Comic In Indonesian Historical Learning to Support Independent Learning at SMA Al-Izzah. In Seminar Nasional Pembelajaran Sejarah (SPNS UNS 2020) (pp. 184-192).

Mahardika, M. D. G. (2020). Kepentingan Rezim dalam Buku Teks Sejarah di Sekolah. ISTORIA: Jurnal Pendidikan Dan Sejarah, 16(2), 1-7.

Mahardika, M. D. G. (2021). Pertimbangan Pemilihan Strategi Pembelajaran Sejarah dengan Orientasi Student Active Learning di SMA. Jurnal Pendidikan Sejarah Indonesia, 4(1), 9-21.

Nordgren, K. (2017). Powerful Knowledge, Intercultural Learning and History Education. Journal of Curriculum Studies, 49(5), 663-68. https:/ / doi.org/https:/ / doi.org/10.1080/00220272.2017.1320430

Priansa, D. J. (2019). Pengembangan Strategi dan Model Pembelajaran: Inovatif, Kreatif, dan Prestatif dalam Memahami Peserta Didik. Pustaka Setia.

Subakti, Y. . (2010). Paradigma Pembelajaran Sejarah ber-basis Konstruktivisme. SPSS, 24.

Sugiyono, P. D. (2014). Metode Penelitian Pendidikan Pendekatan Kuantitatif Kualitatif, dan R \& D. In Pendekatan Kuantitatif. Alfabeta.

Suhendar, Y. (2007). Pedoman Katalogisasi. Kencana.

Sulistyo, W. D., Wicaksana, H., \& Jauhari, N. (2021). Pengembangan Media JESIAMAR (Jelajah Situs Mata Air) di Kota Batu untuk Pembelajaran Sejarah Lokal Era 4.0 Berbasis Foto $360^{\circ}$ di Kelas X SMA Negeri 02 Batu. Cakrawala: Jurnal Pendidikan, 15(1), 64-78. https:/ / doi.org/https://doi.org/10.24905/cakrawala.v15i1.1805

Weingold, M. E. (1972). Studying History Where It Is. The History Teacher, 5(4), 28. https://doi.org/https://doi.org/10.2307/491319

Westerby, G., \& Keegan, K. (2019). Digital Art History and the Museum: The Online Scholarly Collection Catalogues at the Art Institute of Chicago. Visual Resources, 35(1-2), 141-154. https:/ / doi.org/https:/ / doi.org/10.1080/01973762.2018.1553445 
Fahmi Nur Ramadhan, Sunardi, Akhmad Arif Musadad

Media Katalog Digital Untuk Pembelajaran Sejarah

Di Masa Pandemi Covid-19

Whittle, A., \& Wilson, J. (2015). Ethnomethodology and the Production of History: Studying 'History-in-Action.' Business History, 57(1), 41-63. https://doi.org/https://doi.org/10.1080/00076791.2014.977871

Widalismana, M., Baedhowi, \& Sawiji, H. (2016). Pengembangan Media Pembelajaran Berbasis Katalog untuk Meningkatkan Hasil Belajar Siswa Pada Mata Pelajaran Ekonomi di SMA Negeri 5 Surakarta. Jurnal Pendidikan Insan Mandiri, 1(2).

Widja, I. G. (1989). Dasar-Dasar Pengembangan Strategi Serta Metode Pengajaran Sejarah. Depdikbud.

Wynne, S. C. (2009). Cataloging Oral Histories: Creating MARC Records for Individual Oral History Interviews. Cataloging \& Classification Quarterly, 47(6), 561-582.

https://doi.org/https://doi.org/10.1080/01639370902935471 